\title{
Characterisation of nitrogen-containing organic compounds by UHPLC-Qtof-MS and anti-amylase activity from the chloroform extract of the bark of Rhizophora mucronata
}

\author{
P. Resmi, G. Jitha, Vishnu Murali and Anu Gopinath*
}

\begin{abstract}
Background: Medicinal importance of mangrove plant Rhizophora mucronata, a red mangrove species found in the Asian countries, has long been recognised in traditional systems of medicine. The identification of its phytoconstituents can be a starting point for the drug development. The aim of the work was to extend the current knowledge of phytoconstituents from $R$. mucronata and to explore its pharmacological importance in the treatment of diabetes mellitus. In the present study, we analysed the chloroform extract from the bark of the mangrove plant $R$. mucronata for nitrogen-containing constituents using UHPLC QTOF MS profiling, and a-amylase inhibition assay was carried out.

Results: Four nitrogen-containing compounds were identified from the chloroform extract of the bark of $R$. mucronata using UHPLC QTOF MS profiling. The compounds identified were $\mathrm{N}_{1} \mathrm{~N}^{\prime}$-dicyclohexyl urea, a cryptolepine derivative $\left(\mathrm{C}_{17} \mathrm{H}_{15} \mathrm{~N}_{3} \mathrm{O}\right)$, an aliphatic cyclic compound with hydroxyl and amino groups $\left(\mathrm{C}_{22} \mathrm{H}_{43} \mathrm{NO}\right)$, and $\mathrm{C}_{16} \mathrm{H}_{19} \mathrm{NO}_{2}$ ( $\mathrm{m} / \mathrm{z}$ 258.1495). The anti-amylase activity, an in vitro antidiabetic bioassay, of chloroform extract showed an $\mathrm{IC}_{50}$ value of $220.09 \mu \mathrm{g} / \mathrm{ml}$.

Conclusions: This is the first report on the identification of nitrogen-containing compounds from the chloroform extract of the bark of the R. Mucronata. One of the compounds identified was a novel cryptolepine derivative $\left(\mathrm{C}_{16} \mathrm{H}_{13} \mathrm{~N}_{3} \mathrm{O}\right)$, and it falls under the rare category indoloquinoline alkaloid. The chloroform extract also showed significant activity towards a-amylase inhibition assay. Thus, the study has gone some way towards our understanding of the efficacy of bark of the R. mucronata for the treatment of diabetes mellitus and is open for further research.
\end{abstract}

Keywords: Rhizophora mucronata, UHPLC-Qtof-MS, Natural constituents

\section{Background}

Mangrove plants, which come under the broad class halophytes, are grown in coastal regions and their habitats include estuaries, river deltas, and the tidal region near islands [1]. These plants are exposed to several abiotic stress factors (salinity, high temperature, excess of metal

* Correspondence: dranugopinath@gmail.com

Kerala University of Fisheries and Ocean Studies, Kochi, Kerala 682506, India ions, excess of light, and waterlogging conditions) and biotic stress factors (microbial pathogens such as fungi, nematodes, and bacteria along with insects and herbivores) [2]. To survive these stressful environments, they have unique morphological/physiological mechanisms such as photosynthetic pathway, carbohydrate metabolism, and polyphenol synthesise [3]. A well-developed enzymatic (superoxide dismutase, ascorbate peroxidase, etc.) and non-enzymatic (carotenoids, tocopherols, etc.)

\section{Springer Open}

๑ The Author(s). 2021 Open Access This article is licensed under a Creative Commons Attribution 4.0 International License, which permits use, sharing, adaptation, distribution and reproduction in any medium or format, as long as you give appropriate credit to the original author(s) and the source, provide a link to the Creative Commons licence, and indicate if changes were made. The images or other third party material in this article are included in the article's Creative Commons licence, unless indicated otherwise in a credit line to the material. If material is not included in the article's Creative Commons licence and your intended use is not permitted by statutory regulation or exceeds the permitted use, you will need to obtain permission directly from the copyright holder. To view a copy of this licence, visit http://creativecommons.org/licenses/by/4.0/. 
defence system present in the mangroves also helps to mitigate the different stress factors [2]. These protective mechanisms, thus, synthesise a wide variety of secondary metabolites such as terpenes, polyketides, phenolics, alkaloids, amines, and cyanogenic glycosides [4]. Therapeutic effects of these secondary metabolites are the reason behind the usage of mangrove plants in folklore medicine. So, the possibility of finding novel bioactive metabolites from marine organisms and halophytes invites the attention of researchers all over the world [5].

Diabetes mellitus, a metabolic disorder, is considered as one of the major diseases in the world affecting 171 million individuals in 2000 and the projected number is 366 million by 2030 [6]. The disease is characterised by chronic hyperglycaemia resulting from problems in insulin action and/or insulin secretion, which could lead to retinopathy, nephropathy, neuropathy, and angiopathy [7]. Researchers around the globe are searching for new phytochemical formulations with lower side effects for the treatment of diabetes mellitus.

Rhizophora mucronata, which is a true red mangrove coming under the genera Rhizophora [8], is used as a traditional medicine to treat several diseases such as diabetes, constipation, nausea, haematuria, and diarrhoea [9]. It is a common plant species found in East Africa, Australia, and India [10]. A number of compounds such as terpenoids, phenolics, and ketones were reported previously from this plant [8]. Triterpenoids such as $3 \beta-E-$ caffeoyltaraxerol, $3 \beta$-Z-caffeoyltaraxerol, $3 \beta$-E-p-coumaroyltaraxerol, taraxerol, lupeol, 33-O-(E)-(4-methoxy)cinnamoyl-15 $\alpha$-hydroxyl- $\beta$-amyri oleanolic acid, $\beta$ amyrin, ursolic acid and $\alpha$-amyrin [10], and alkaloid (Rhizophorine) [11] were also reported from this plant.

The bark of the mangrove plant $R$. mucronata is used for diabetic treatment in folklore medicine. Most of the previous studies on antidiabetic activities of this plant were focused on the natural constituents from the crude methanolic or aqueous extract. The crude extracts may contain a large number of metabolites in trace amounts; therefore, fractionation has to be carried out to get active metabolites. Fractionation of the extract from the bark and subsequent identification of nitrogen-containing compounds from $R$. mucronata were not available in the literature. In the present study, we are attempting the identification of natural constituents from chloroform extract obtained by the liquid-liquid partitioning of the ethanolic extract. The main objective of the proposed work is the chromatographic separation and mass spectrometric identification of nitrogenous organic compounds from the chloroform extract of bark of the mangrove plant $R$. mucronata. The study also aims to explore the antidiabetic activity of the chloroform fraction of bark by $\alpha$-amylase inhibition assay.

\section{Methods}

Mangrove plant $R$. mucronata (Fig. 1) was collected from the mangrove swamps of Panangad, Kochi, Kerala, on the southwest coast of India. The plant was authenticated and accession number for the plant species (Accession No:18174) was obtained from KFRI-herbarium, Forest Botany Department, Kerala Forest Research Institute, Kerala.

The plant was washed with cold running water and then the bark was separated. The bark was shade dried for one week, and the powdered bark was used for the extraction of natural constituents. The extraction of the organic constituents was achieved using ethanol maceration. Maceration was carried out for 7 days and the filtrate was collected thrice from the sample. Filtrate was then concentrated using a rotary evaporator, and the fatty components were removed by liquid-liquid partitioning with hexane. The extract was then made basic by the addition of ammonia ( $\mathrm{pH} 9$ ), and the precipitate formed was removed by the filtration. Chloroform fraction of the filtrate was collected by liquid-liquid partitioning and was used for the isolation of natural constituents. The chloroform layer was further dried under vacuum using rotary evaporator. The column

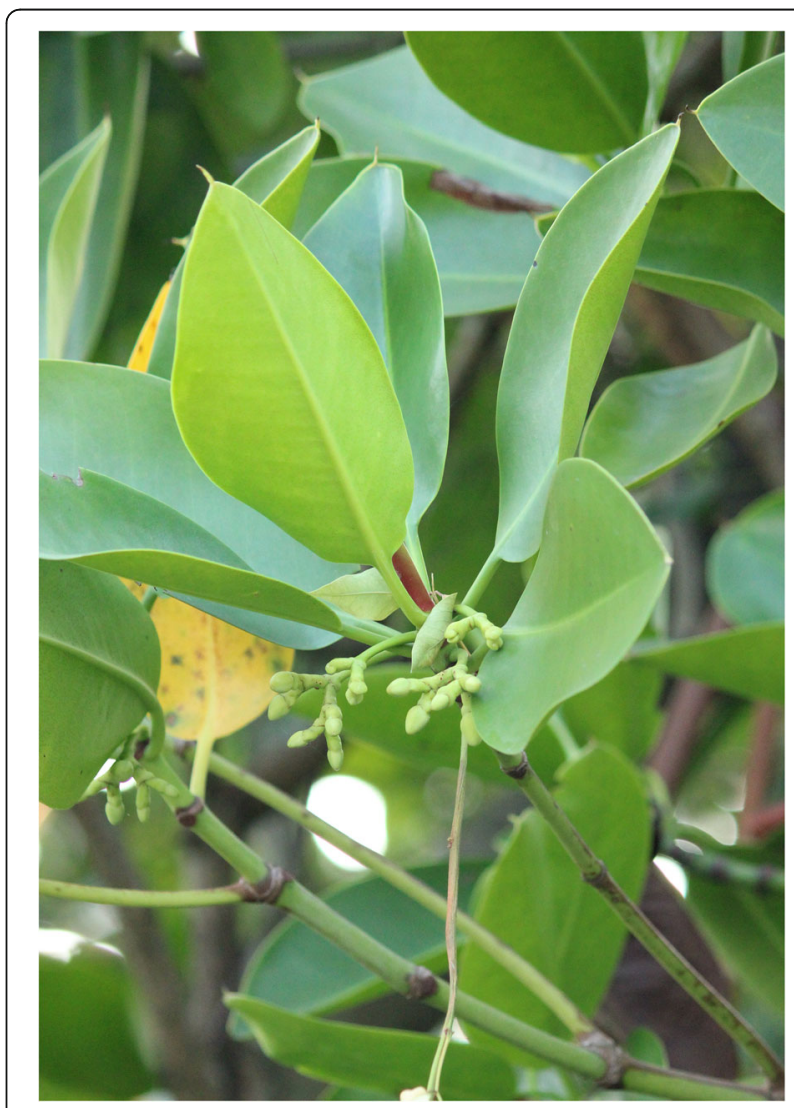

Fig. 1 Mangrove plant $R$. mucronata collected from Panangad swamp, Kerala 
chromatography (silica gel Merck 10-200 mesh) was used for the separation of natural constituents with gradient elution (hexane:ethyl acetate 4\%, 8\% ...100\% followed by ethyl acetate: methanol 16.66\%, 33.33\%... $100 \%)$. The fraction which responded positively with dragendorff reagent was further purified with TLC and then identified with UHPLC-Qtof-MS (ultrahigh performance liquid chromatography-quadrupole time-offlight-mass spectrometry).

\section{Conditions of UHPLC-Qtof-MS}

The sample was analysed using UHPLC (ultrahigh performance liquid chromatography) equipped with quadrupole time-of-flight mass spectrometry (QTof). A model Acquity UPLC (Waters, MA, USA) coupled with Xevo G2 XS QTof equipped with electrospray ion source (ESI) was used for the analysis. The separation was achieved using the reverse phase BEH C18 column $(50 \mathrm{~mm} \times 2.1 \mathrm{~mm} \times 1.7 \mu \mathrm{m})$. Separation of individual ions was facilitated by gradient elution of acetonitrile (A) and $0.1 \%$ formic acid in water (B) at a flow rate of 0.3 $\mathrm{mL} / \mathrm{min}$. Experiments were performed in positive ESI (electronspray ionisation) mode with the desolvation gas flow $900 \mathrm{~L} / \mathrm{h}$ and temperature $350{ }^{\circ} \mathrm{C}$. The scan range of MS was between 50 and $2000 \mathrm{~m} / \mathrm{z}$. The $10 \mu \mathrm{l}$ of the sample was introduced into the instrument for analysis. The mass spectrum was obtained using collision energy 5 to $30 \mathrm{eV}$. The organic compounds were identified by using $[\mathrm{M}+\mathrm{H}]^{+}$peak and its fragmentation patterns. A mass correction was carried out with leucine enkephalin in every $2.5 \mathrm{~min}$. The MassLynx 4.1 software was used for the instrument control. The structural elucidation of metabolites was carried out with the help of application software and databases such as melin, Siuzdak Lab at Scripps Research; Pubchem, United States National Institutes of Health and Chemspider, Royal Society of Chemistry.

\section{Antidiabetic activity using a-amylase inhibition assay}

Amylase activity was assayed using a modified Bernfeld method [12] using starch as substrate and the sugar formed was estimated using DNSA assay. Different concentration of the extracts $(100 \mu \mathrm{L}$, triplicate) and $100 \mu \mathrm{L}$ $\alpha$-amylase solution $(0.5 \mathrm{mg} / \mathrm{mL}$ in $0.02 \mathrm{M}$ sodium phosphate buffer saline with $\mathrm{pH} 6.9$ with $0.006 \mathrm{M} \mathrm{NaCl}$ ) were incubated at $25^{\circ} \mathrm{C}$ for $10 \mathrm{~min}$. After pre-incubation, 100 $\mu \mathrm{L}$ of a $1 \%$ starch solution in sodium phosphate buffer was added to each tube. The reaction mixtures were incubated at $25{ }^{\circ} \mathrm{C}$ for $10 \mathrm{~min}$. The reaction was stopped with $200 \mu \mathrm{L}$ of dinitrosalicylic acid colour reagent. The test tubes were incubated in a boiling water bath for 5 min and cooled to room temperature. The reaction mixture was then diluted and made up to $3 \mathrm{~mL}$ using distilled water, and absorbance was measured at $540 \mathrm{~nm}$ using UV visible spectrophotometer. The absorbance of blanks (without enzyme) and a control (buffer in place of sample extract) were also measured.

$$
\text { \%Inhibition }=100 \times \frac{\text { Abs control-Abs sample }}{\text { Abs control }}
$$

$\mathrm{Abs}_{\text {sample }}$ is the difference between absorbance of the sample with or without enzyme. $\mathrm{IC}_{50}$ shows $50 \%$ inhibition for the sample. $\mathrm{IC}_{50}$ can be calculated from the graph using the equation of the straight line that plotted between the concentration of the extract and \% inhibition ( $\mathrm{y}=\mathrm{a}+\mathrm{bx}, \mathrm{IC}_{50}$ can be calculated by putting $\mathrm{y}=50$ ). Acarbose, a standard inhibitor of the enzyme $\alpha$-amylase, served as a reference standard.

\section{Results}

Chemical characterisation of the chloroform fraction of the bark of $R$. mucronata was carried out using UHPLCQtof-MS profiling and four nitrogen-containing compounds were identified. Experiments were accomplished by positive ESI mode and following $[\mathrm{M}+\mathrm{H}]^{+}$of the compounds were identified : $\mathrm{m} / \mathrm{z} 225.1965\left(\mathrm{C}_{13} \mathrm{H}_{24} \mathrm{~N}_{2} \mathrm{O}\right), \mathrm{m} /$ z $338.3428\left(\mathrm{C}_{22} \mathrm{H}_{43} \mathrm{NO}\right), \mathrm{m} / \mathrm{z} 278.1295\left(\mathrm{C}_{16} \mathrm{H}_{13} \mathrm{~N}_{3} \mathrm{O}\right)$, and $\mathrm{m} / \mathrm{z} \mathrm{C}_{16} \mathrm{H}_{19} \mathrm{NO}_{2}$ (258.1495).

Compound $1\left[\mathrm{C}_{13} \mathrm{H}_{24} \mathrm{~N}_{2} \mathrm{O}\right.$; m/z 225.1965] was identified as $\mathrm{N}, \mathrm{N}^{\prime}$-dicyclohexyl urea from the mass spectral database (Melin, Siuzdak Lab at Scripps Research). Compound $2\left[\mathrm{C}_{22} \mathrm{H}_{43} \mathrm{NO} ; \mathrm{m} / \mathrm{z} 338.3428\right]$ showed the fragmentation patterns of an aliphatic compound. Compound $3\left[\mathrm{C}_{16} \mathrm{H}_{13} \mathrm{~N}_{3} \mathrm{O} ; \mathrm{m} / \mathrm{z}\right.$ 278.1295] was an aromatic compound. Mass fragmentation of the isolated compound showed a fragment at $\mathrm{m} / \mathrm{z} 218.0844$ $\left(\mathrm{C}_{15} \mathrm{H}_{10} \mathrm{~N}_{2}\right)$ corresponding to quindoline [13]. Compound $4\left[\mathrm{C}_{16} \mathrm{H}_{19} \mathrm{NO}_{2}, \mathrm{~m} / \mathrm{z} 258.1495\right]$ was an unknown aromatic compound. Mass spectrum of the compounds is given in Figs. 2 and 3.

The antidiabetic activity of the chloroform extract was assessed using $\alpha$-amylase inhibition activity. $\mathrm{IC}_{50}$ value was calculated from the graph drawn between the $\%$ inhibition of $\alpha$-amylase and the concentration of the extract (Fig. 4) and was found to be $220.09 \mu \mathrm{g} / \mathrm{ml}$. $\alpha$ Amylase inhibition assay of acarbose showed an $\mathrm{IC}_{50}$ of $38.40 \mu \mathrm{g} / \mathrm{ml}$.

\section{Discussion}

The presence of chemical constituents such as sugar, tannins, saponins, alkaloids, flavonoids, steroids, terpenoids, glycosides, phenolics, gibberellins, lipids, inositols, anthocyanidins, polysaccharides, proteins, minerals, hydrolysable tannins, and polyphenols were previously reported from R. mucronata [10]. Most of the chemical constituents were reported from the leaf and root of the plant, but the information about the metabolites isolated 

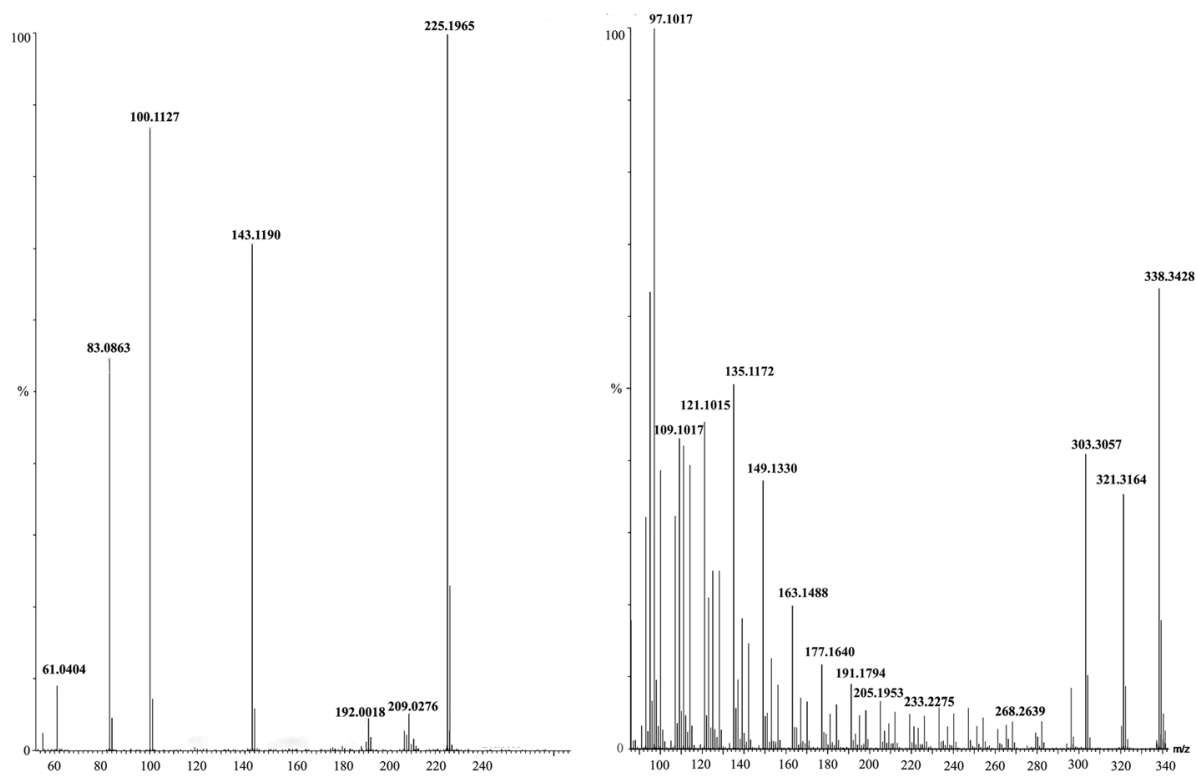

Fig. 2 UHPLC-Qtof mass spectrum of identified compounds from the chloroform extract. (1) m/z ratio: 225.1965 and (2) m/z ratio: 338.3428

from the chloroform extract of the bark is rare in literature. In the present study, the following compounds were identified from the chloroform extract of the bark by the mass spectral studies.

Compound 1 (N,N'-Dicyclohexylurea): N,N'-Dicyclohexylurea was reported for the first time from the plant $R$. mucronata. The MS fragmentation pattern of dicylcohexyl urea is given in Fig. 5. N,N'-Dicyclohexylurea was previously reported from the plants Toddalia Asiatica [14] and
Portulaca Oleraceae [15]. This compound possesses antibacterial activity against Escherichia coli [16] and acts as a ubiquinone reduction inhibitor [17] and soluble epoxide hydrolase (sEH) inhibitor [18]. sEH inhibitors may be used as a drug for the treatment of diabetes, hypertension, stroke, dyslipidaemia, pain, immunological disorders, eye diseases, and neurological diseases by increasing epoxy eicosatrienoic acid concentration and decreasing dihydroxy eicosatrienoic acids [19].
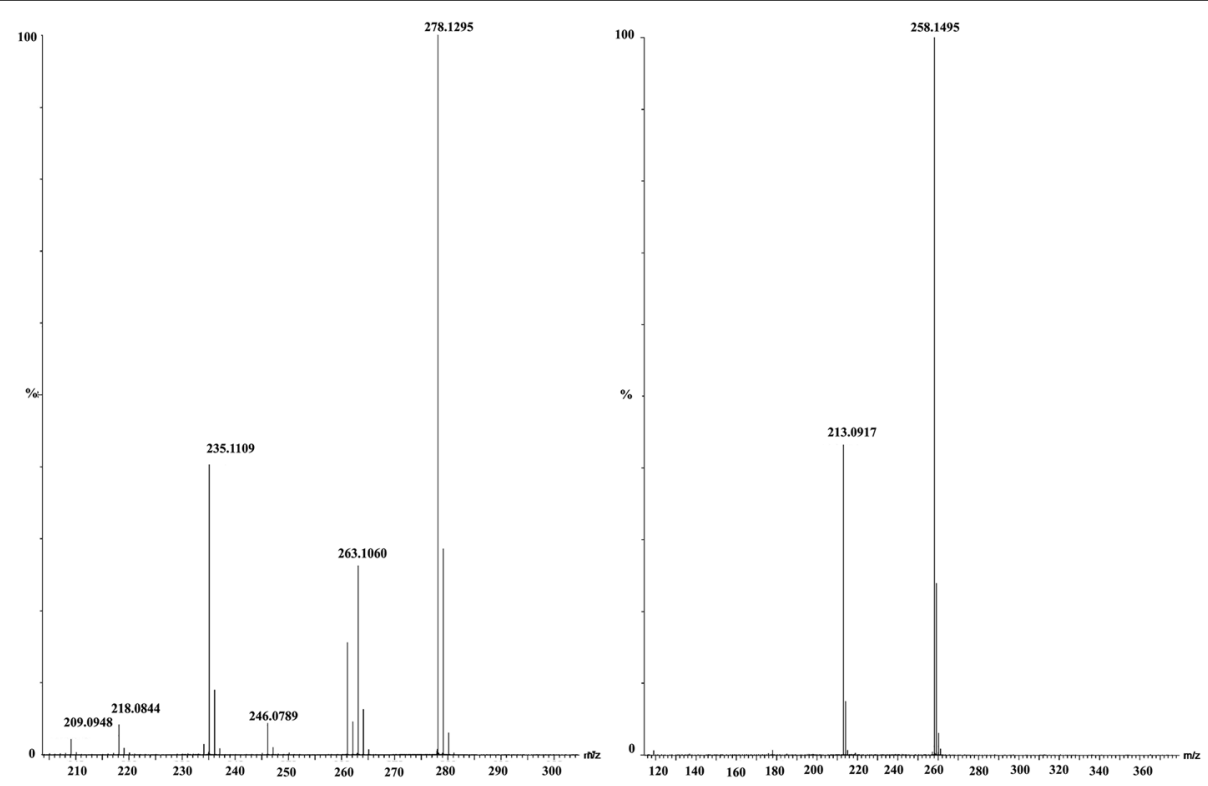

Fig. 3 UHPLC-Qtof mass spectrum of identified compounds from the chloroform extract. (1) m/z ratio: 278.1295 and (2) m/z ratio: 258.1495 


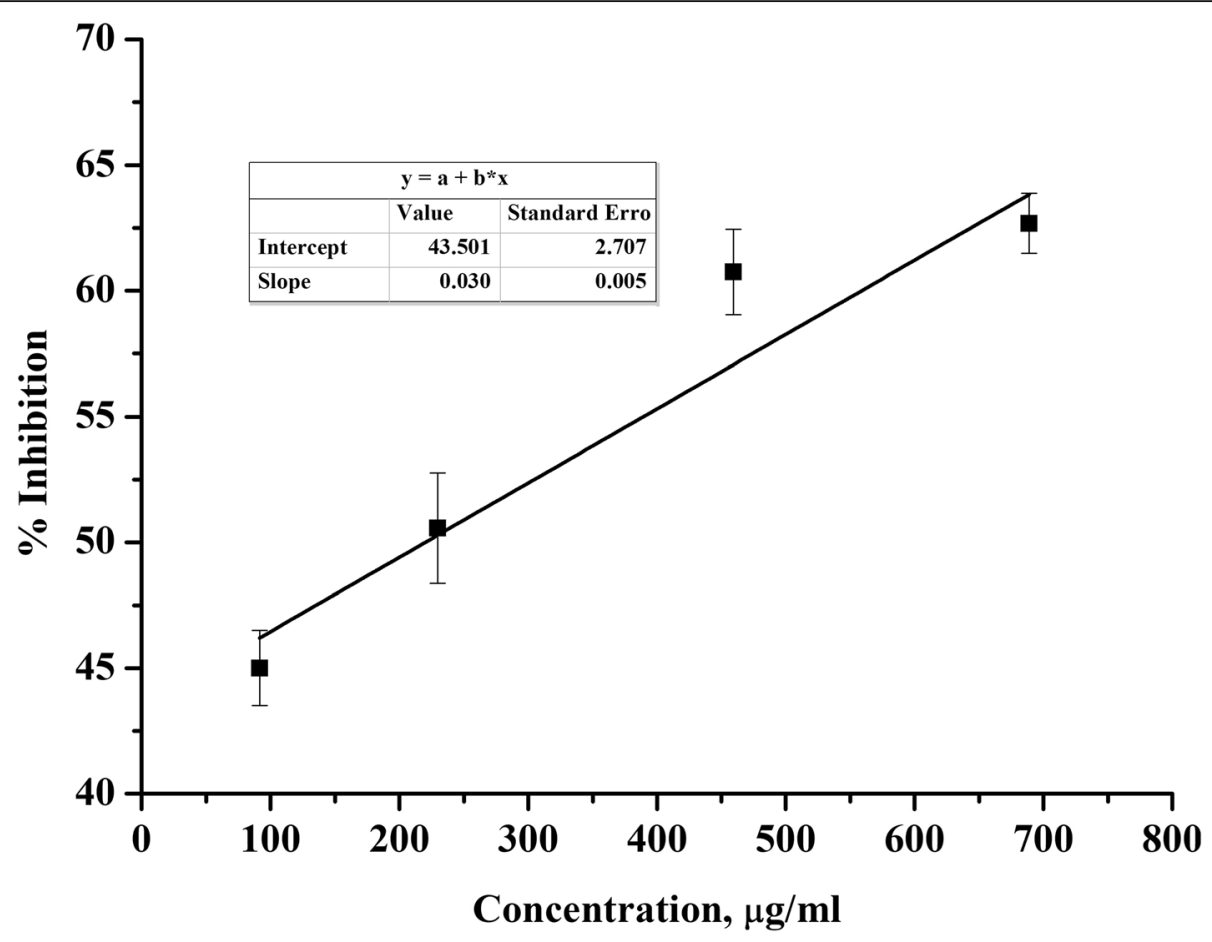

Fig. $4 \%$ Inhibition of a-amylase by chloroform fraction of the bark extract of R. mucronata

Compound 2: It is an unknown compound with the molecular formula $\mathrm{C}_{22} \mathrm{H}_{43} \mathrm{NO}$, having molecular ion peak at $\mathrm{m} / \mathrm{z} 338.3428$. It shows the characteristic homologous peaks for aliphatic compound by cleaving down the chain at $\mathrm{C}-\mathrm{C}$ bonds. A fragment formed at $\mathrm{m} / \mathrm{z}$
321.3164 by the cleavage of $-\mathrm{C}-\mathrm{N}$ bond is due to the elimination of $\mathrm{NH}_{3}\left([\mathrm{M}+\mathrm{H}]^{+}-17.0264\right)$. Another fragment at $\mathrm{m} / \mathrm{z} 303.3057$ is due to the loss of $\mathrm{H}_{2} \mathrm{O}$ indicating the presence of hydroxyl group $(-\mathrm{OH})$. The fragment at $\mathrm{m} / \mathrm{z} 97.1017$ corresponds to $\mathrm{C}_{7} \mathrm{H}_{13}{ }^{+}$and is a

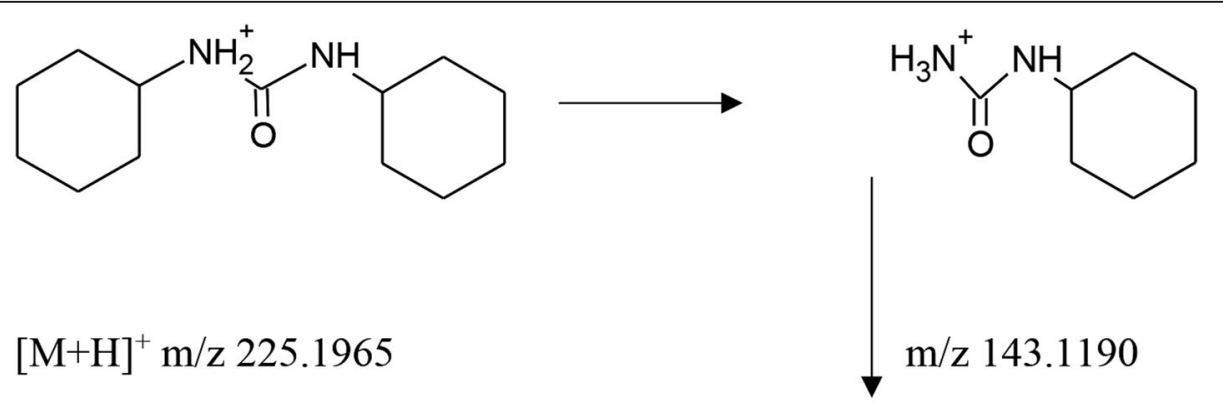<smiles>[C+]1CCCCC1</smiles><smiles>[NH3+]C1CCCCC1</smiles>

$\mathrm{m} / \mathrm{z} 83.0863$

$\mathrm{m} / \mathrm{z} 100.1127$

Fig. 5 Proposed chemical structure of dicyclohexyl urea and its fragment ions with the respective exact masses 
characteristic feature of an aliphatic cyclic group. The proposed fragmentation pattern of the cyclic part of the compound is given in Fig. 6.

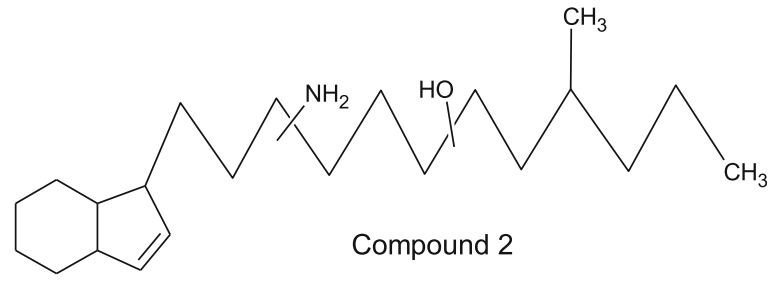

So, the compound identified is a $\mathrm{C}_{22}$ aliphatic cyclic compound with functional groups hydroxyl and primary amine.

Compound 3: $[\mathrm{M}+\mathrm{H}]^{+}$peak at $\mathrm{m} / \mathrm{z}$ 278.1295. The molecular formula of the compound is calculated as $\mathrm{C}_{17} \mathrm{H}_{15} \mathrm{~N}_{3} \mathrm{O}$.

The fragments with $\mathrm{m} / \mathrm{z}$ values $263.1060\left(\mathrm{C}_{16} \mathrm{H}_{13} \mathrm{~N}_{3} \mathrm{O}\right)$ and $246.0789\left(\mathrm{C}_{16} \mathrm{H}_{10} \mathrm{~N}_{2} \mathrm{O}\right)$ indicate the loss of methyl group $\left([\mathrm{M}+\mathrm{H}]^{+}-15.0235\right)$ followed by the loss of ammonia $\left([\mathrm{M}+\mathrm{H}]^{+}-\mathrm{CH}_{6} \mathrm{~N}\right)$. These fragments reveal the presence of the methyl and amine $\left(-\mathrm{NH}_{2}\right)$ group in the compound. Another fragment at $\mathrm{m} / \mathrm{z} 235.1109$ $\left(\mathrm{C}_{15} \mathrm{H}_{13} \mathrm{~N}_{3}:[\mathrm{M}+\mathrm{H}]^{+}-43.0188\right)$ resulted from the loss of $-\mathrm{C}_{2} \mathrm{H}_{3} \mathrm{O}\left(-\mathrm{CH}_{3}\right.$ and $\left.-\mathrm{CO}\right)$ group from the molecular ion suggests the presence of $-\mathrm{C}=\mathrm{O}$ moiety in the compound. The fragment at $\mathrm{m} / \mathrm{z} 218.0844$, formed by the loss of all the groups discussed above $\left(-\mathrm{CH}_{3},-\mathrm{NH}_{2}\right.$ and $\left.-\mathrm{CO}\right)$ from the molecular ion, is identical to that of quindoline. Literature shows that mass fragmentation of cryptolepine leads to the formation of quindoline fragment with $\mathrm{m} / \mathrm{z}$ 218.0844 by the neutral loss of $-\mathrm{CH}_{3}$ [13]. The fragment with $\mathrm{m} / \mathrm{z} 209.0948\left(\mathrm{C}_{13} \mathrm{H}_{11} \mathrm{~N}_{3}{ }^{+}\right)$formed by the loss of $\mathrm{C}_{4} \mathrm{H}_{5} \mathrm{O} \quad(\mathrm{m} / \mathrm{z} \quad 235.1109-\mathrm{CH} \equiv \mathrm{CH})$ i.e. loss of $\mathrm{C}_{2} \mathrm{H}_{2}-$ $\mathrm{COCH}_{3}\left([\mathrm{M}+\mathrm{H}]^{+}-69.0344\right)$ from the molecular ion confirms the presence of - $\mathrm{CO}$ group in the molecule.

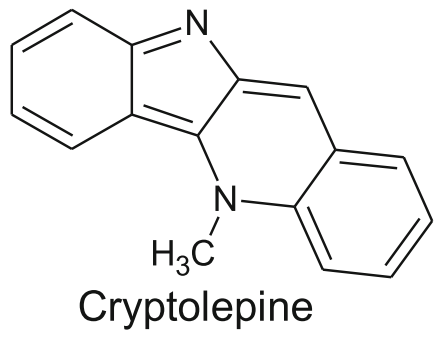

The proposed structure and fragmentation of the compound is given in Fig. 7. The most remarkable result to emerge from these spectral data is the identification of a novel derivative of cryptolepine which belongs to the class of indoloquinoline alkaloid.

The indoloquinoline family of alkaloids is a very rare group of natural products. Examples are cryptolepine [20], quindoline [13], and the complex spiro-nonacyclic alkaloid cryptospirolepine [21]. Cryptolepine was reported from a shrub Cryptolepis sanguinolenta which is indigenous to West Africa and has long been used for the treatment of various fevers, including malaria [20]. So, the novel compound identified may have the potential therapeutic values which are open to further study.<smiles>COC(C)O[Na]</smiles>

Compound 4: Molecular ion $[\mathrm{M}+\mathrm{H}]^{+}$with $\mathrm{m} / \mathrm{z}$ 258.1495. This is an unknown compound with the molecular formula $\mathrm{C}_{16} \mathrm{H}_{19} \mathrm{NO}_{2}$. Only two fragments were observed in the mass spectra, a molecular ion peak and a fragment at $\mathrm{m} / \mathrm{z} 213.0917$. The data is inadequate for the complete characterisation of the compound. The fragment formed at $\mathrm{m} / \mathrm{z} 213.0917\left(\mathrm{C}_{14} \mathrm{H}_{13} \mathrm{O}_{2}{ }^{+}\right)$indicates the elimination of $-\mathrm{C}_{2} \mathrm{H}_{7} \mathrm{~N}\left([\mathrm{M}+\mathrm{H}]^{+}-45.0578\right)$. From these available spectral data, the compound can be interpreted as an aromatic compound with amine functional group.

\section{Antidiabetic activity using a-amylase inhibition assay}

The chemical constituents such as glycosides, alkaloids, terpenoids, flavonoids, carotenoids, tannins, and polyphenolic derivatives are being used for diabetic treatment [22]. Of these, alkaloids are nitrogen-containing organic compounds which show antidiabetic activity either by enhancing insulin secretion from the pancreas or by reducing the blood glucose level by its transport to<smiles>[CH2+]C1CCC(C=[C+]C=CC2CCCCC2)CC1</smiles>

$\mathrm{m} / \mathrm{z} 121.1015$

$\mathrm{m} / \mathrm{z} 109.1017$

$\mathrm{m} / \mathrm{z} 97.1017$

Fig. 6 Proposed chemical structure of compound 2 and its fragment ions with the respective exact masses 

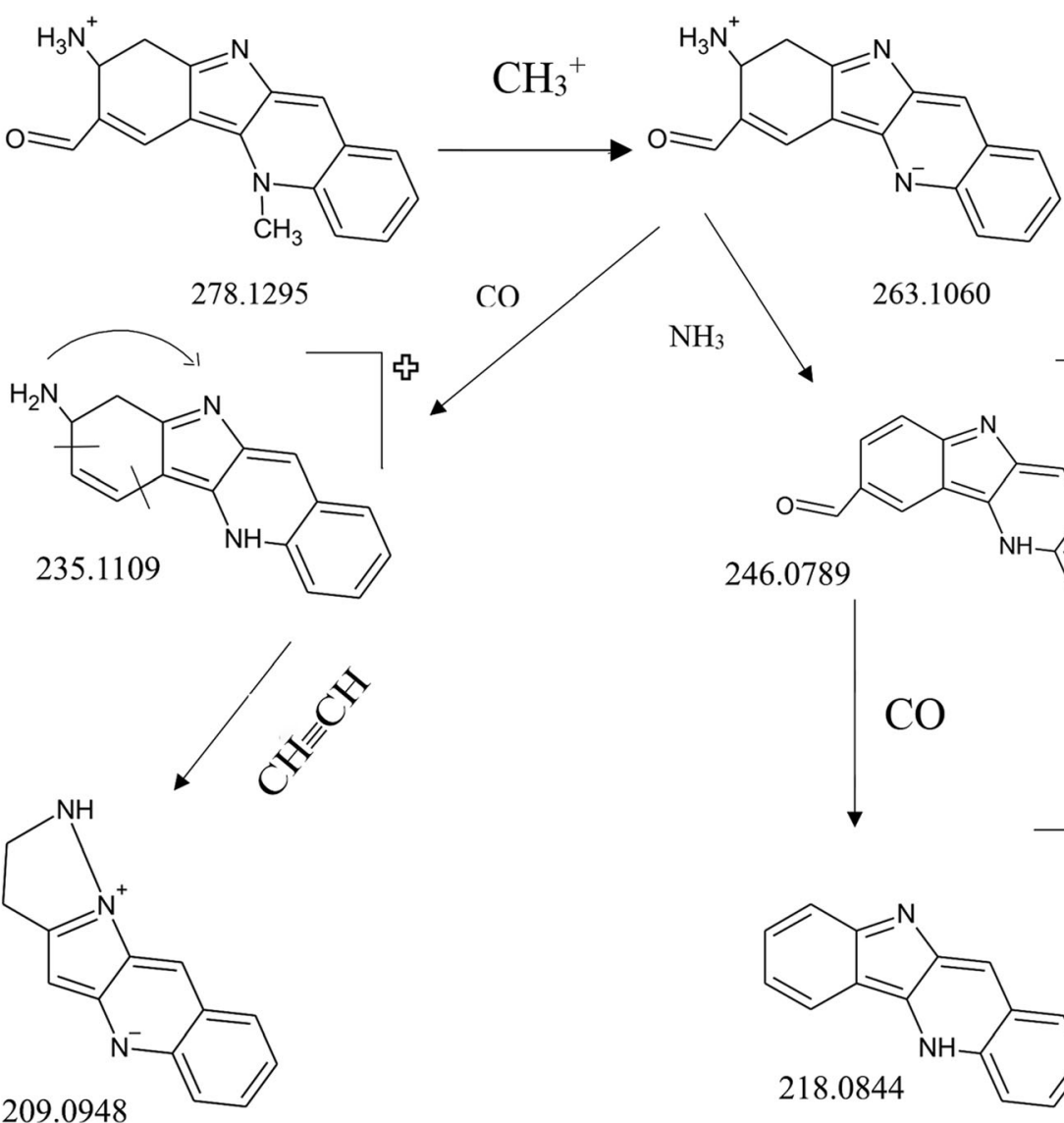

$\mathrm{CO}$
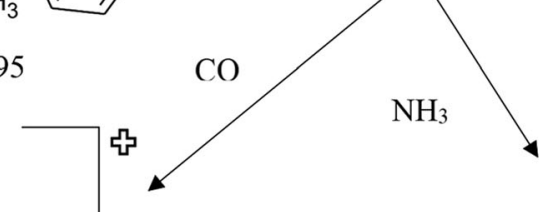

263.1060

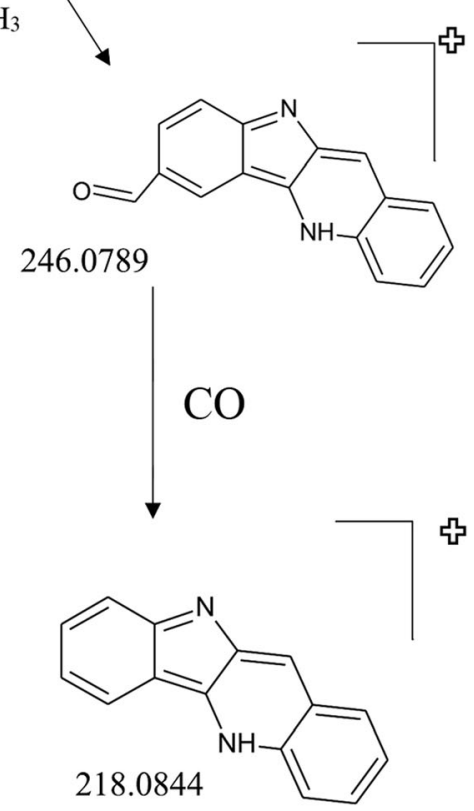

Fig. 7 Proposed chemical structure of compound 3 and its fragment ions with the respective exact masses

peripheral tissue [23]. Antidiabetic activity of alkaloids from the plants Aerva lanata, Catharanthus roseus (L.) G, and the steroidal alkaloid of Sarcococca saligna were reported in previous studies [24-26]. Acanthicifoline and trigonellin were the alkaloids isolated from the mangrove plant Acanthus ilicifolius [27].

$R$. mucronata is used as a traditional medicine for diabetes in India [2]. Antidiabetic potential studies of aqueous leaf extract of R. mucronata in the alloxan-induced diabetic rats by oral administration showed the reduction of blood glucose to normal levels. It was correlated to the presence of insulin-like protein in the extracts [28]. Antidiabetic activity of the aqueous bark extracts of $R$. mucronata was reported, and the proposed pathway was the glucose absorption inhibition [29].

One of the therapeutic approaches for diabetes mellitus is done by decreasing glucose absorption through the inhibition of carbohydrate hydrolysing enzymes [10]. $\alpha$-Amylase is a carbohydrate hydrolysing enzymes, and its inhibition can be used as firsthand information for antidiabetic activity. The reports on $\alpha$-amylase inhibition activity from chloroform fraction from the bark of $R$. mucronata are scarce in the literature. In the present study, $\alpha$-amylase inhibition activity was assessed for chloroform fraction and the $\mathrm{IC}_{50}$ value was found to be $220.09 \mu \mathrm{g} / \mathrm{ml}$. For acarbose, a standard drug that works in a similar fashion showed an $\mathrm{IC}_{50}$ of $38.40 \mu \mathrm{g} / \mathrm{ml}$. The $\mathrm{IC}_{50}$ value of the extract suggests promising activity towards the $\alpha$-amylase inhibition, even though its activity is less than that of acarbose. At this stage, considering only the $\alpha$-amylase inhibition activity, it is difficult to arrive at any conclusion regarding the therapeutic use of the extract. Additional in vitro and in vivo animal testing and cytotoxic studies must be conducted to get more conclusions regarding the drug formulations for diabetic treatment.

\section{Conclusion}

R. mucronata, which is rich in phytochemicals, has been used as a traditional medicine for various types of diseases. Most of the previous studies on these phytochemicals were mainly focused on the crude extract, from which the chemical characterisation of the natural constituents was very difficult. The present study is designed 
to evaluate the nitrogen-containing phytochemicals from the chloroform fraction of the bark of the mangrove plant $R$. mucronata, which is not available in the literature. We have identified four nitrogen-containing compounds by spectroscopic methods (UHPLC-Qtof-MS). One of the compounds identified from this plant, N,N '-dicyclohexyl urea $\left(\mathrm{C}_{13} \mathrm{H}_{24} \mathrm{~N}_{2} \mathrm{O}\right)$, which is an sEH inhibitor, is reported for the first time. The investigation also reveals the presence of novel cryptolepine derivative $\left(\mathrm{C}_{17} \mathrm{H}_{15} \mathrm{~N}_{3} \mathrm{O}\right)$ of indoloquinoline alkaloid class. From the study, an aliphatic compound $\left(\mathrm{C}_{22} \mathrm{H}_{43} \mathrm{NO}\right)$ with hydroxyl and amine functional groups and an unknown aromatic compound $\left(\mathrm{C}_{16} \mathrm{H}_{19} \mathrm{NO}_{2}\right)$ were also identified. Since the bark of the plant is used in traditional systems of medicine for diabetic treatment, we also explored its efficacy using $\alpha$-amylase inhibition assay. The chloroform fraction, which contains the above natural constituents, showed a promising $\alpha$-amylase inhibition. Thus, the study gives some insight into the antidiabetic activity of R. mucronata and is open for further developments such as in vitro, in vivo, and cytotoxic studies for formulating drugs for the treatment of diabetes.

\section{Abbreviations}

UHPLC QTOF MS: Ultrahigh performance liquid chromatography-quadrupole time-of-flight-mass spectrometry; R. mucronata: Rhizophora mucronata;

ESI: Electronspray ionisation; sEH: Soluble epoxide hydrolase

\section{Acknowledgements}

The authors thank the Kerala State Council for Science and Technology for funding the postdoctoral fellowship for Dr Resmi P and Jitha G for the financial support. The authors also acknowledged Inter-University Instrumentation Centre, M G University, Kottayam for UHPLC-Qtof-MS analysis.

\section{Plant authentication}

The plant was authenticated as Rhizophora mucronata by Dr. Prabhakaran M $P$, Assistant professor in fisheries oceanography, Kerala University of Fisheries and Ocean Studies. Accession number for the plant species (Accession No: 18174) was obtained from KFRI-herbarium (e-mail: herbarium@kfri.res.in), Forest Botany Department, Kerala Forest Research Institute, Kerala.

\section{Authors' contributions}

RP designed and performed the experimental part and guidance for the work is provided by AN. The result analysis was performed by RP and VM. $R P, A G$, and JG contributed to the preparation of the manuscript. The final manuscript was read and approved by all authors.

\section{Funding}

The authors thank the Kerala State Council for Science and Technology for funding the postdoctoral fellowship for Dr Resmi P (777/2018/KSCSTE) and Jitha G (749/2019/KSCSTE) for the financial support as fellowship. Purchase of chemicals and analysis charges were supported by the contingency of the post-doctoral fellowship of Dr. Resmi P.

\section{Availability of data and materials}

All data and materials are available upon request.

\section{Declarations}

Ethics approval and consent to participate

Not applicable

\section{Consent for publication}

Not applicable

\section{Competing interests}

The authors declare that they have no competing interests.

Received: 17 February 2021 Accepted: 15 June 2021

Published online: 08 July 2021

\section{References}

1. Tomlinson PB (1986) The botany of mangroves. Cambridge University Press, United Kingdom

2. Das SK, Patra JK, Thatoi H (2016) Antioxidative response to abiotic and biotic stresses in mangrove plants: A review. Int Rev Hydrobiol 101(1-2):319. https://doi.org/10.1002/iroh.201401744

3. Bandaranayake WM (2002) Bioactivities, bioactive compounds and chemical constituents of mangrove plants. Wetl Ecol Manag 10(6):421-452. https:// doi.org/10.1023/A:1021397624349

4. Wink M (2010) Annual plant reviews biochemistry of plant secondary metabolism, 2nd edn. Wiley-Blackwell Publishing Ltd., Chichester, UK. https://doi.org/10.1002/9781444320503

5. Jimeno J, Faircloth G, Sousa-Faro JM, Scheuer P, Rinehart K (2004) New marine derived anticancer therapeutics - a journey from the sea to clinical trials. Mar Drugs 2(1):14-29. https://doi.org/10.3390/md201014

6. Wild S, Roglic G, Green A, Sicree R, King H (2004) Global prevalence of diabetes Estimates for the year 2000 and projections for 2030. Diabetes Care 27(5):1047-1053. https://doi.org/10.2337/diacare.27.5.1047

7. Etxeberria U, de la Garza AL, Campión J, Martinez JA, Milagro FI (2012) Antidiabetic effects of natural plant extracts via inhibition of carbohydrate hydrolysis enzymes with emphasis on pancreatic alpha amylase. Expert Opin Ther Targets 16(3):269-297. https://doi.org/10.1517/14728222.2012. 664134

8. Nebula M, Harisankar HS, Chandramohanakumar N (2013) Metabolites and bioactivities of Rhizophoraceae mangroves. Nat Prod Bioprospect 3(5):207232. https://doi.org/10.1007/s13659-013-0012-0

9. Bandaranayake WM (1998) Traditional and medicinal uses of mangroves. Mangrove Salt Marshes 2(3):133-148. https://doi.org/10.1023/A:1 009988607044

10. Nabeelah BS, Fawzi MM, Gokhan Z, Rajesh J, Nadeem N et al (2019) Ethnopharmacology, phytochemistry, and global distribution of mangroves-a comprehensive review. Mar Drugs 17(4):231. https://doi. org/10.3390/md17040231

11. Saha PK, Ganguly T, Ganguly SN, Sircar SM (1978) Rhizophorine, a new indole acid plant growth inhibitor from Rhizophora mucronata. Plant Biochem J 5:65-68

12. Bernfeld P (1955) Amylases a and b: colorimetric assay method. Methods Enzymol 1:149-158. https://doi.org/10.1016/0076-6879(55)01021-5

13. Calderón Al, Hodel A, Wolfender JL, Gupta MP, Correa M, Hostettmann K (2013) LC-DAD-MS-based metabolite profiling of three species of Justicia (Acanthaceae). Nat Prod Res 27(15):1335-1342. https://doi.org/10.1080/14 786419.2012 .738207

14. Tsai IL, Fang SC, Ishikawa T, Chang CT, Chen IS (1997) N-cyclohexyl amides and a dimeric coumarin from formosan Toddalia asiatica. Phytochemistry 44(7):1383-1386. https://doi.org/10.1016/S0031-9422(96)00724-8

15. Rashed AN, Afifi FU, Shaedah M, Mutasem O (2004) Investigation of the active constituents of Portulaca Oleraceae L. (Portulacaceae) growing in Jordan. Pak J Pharm Sci 17:37-45

16. Tomassino M, Capaldi RA (1985) Effect of dicyclohexylcarbodiimide on unisite and multisite catalytic activities of the adenosine triphosphatase of Escherichia coli. Biochemistry 24(15):3972-3976. https://doi.org/10.1021/ bi00336a026

17. Yagi T (1987) Inhibition of NADH-ubiquinone reductase by $\mathrm{N} \mathrm{N}^{\prime}$ dicyclohexylcarbodiimide and correlation of this inhibition with the occurrence of energy-coupling site 1 in various organisms. Biochemistry 26(10):2822-2828. https://doi.org/10.1021/bi00384a025

18. Ghosh S, Chiang PC, Wahlstrom JL, Fujiwara H, Selbo JG, Roberds SL (2008) Oral delivery of 1, 3-dicyclohexylurea nanosuspension enhances exposure and lowers blood pressure in hypertensive rats. Basic Clin pharmacol 102(5): 453-458. https://doi.org/10.1111/j.1742-7843.2008.00213.x

19. Shen HC (2010) Soluble epoxide hydrolase inhibitors: a patent review. Expert Opin Ther Pat 20(7):941-956. https://doi.org/10.1517/13543776.2010.4 84804

20. Clinquart E (1929) Sur la Compesition Chimnique de "Cryptolepis triangularis" plante congolaise. Bull Mem Acad R Med Belg 12:627-635 
21. Tackie AN, Boye GL (1993) Cryptospirolepine, a unique spiro-nonacyclic alkaloid isolated from Cryptolepis sanguinolenta. J Nat Prod 56(5):653-670. https://doi.org/10.1021/np50095a001

22. Bailey CJ, Day C (1989) Traditional plant medicines as treatments for diabetes. Diabetes Care 12(8):553-564. https:/doi.org/10.2337/diacare.12.8.553

23. Gulfraz M, Ahmad A, Asad MJ, Sadiq A, Afzal U, Imran M (2011) Antidiabetic activities of leaves and root extracts of Justia adhatoda Linn. against alloxan induced diabetes in rats. Afr J Biotechnol 10:6101-6106. https://doi.org/10. 5897/AJB10.1186

24. Jan NU, Ali A, Ahmad B, Iqbal N, Adhikari A, Ali A, Ali S, Jahan A, Ali H, Ali I, Ullah A (2018) Evaluation of antidiabetic potential of steroidal alkaloid of Sarcococca saligna. Biomed Pharmacother 1:461-466. https://doi.org/10.101 6/j.biopha.2018.01.008

25. Tiong SH, Looi CY, Hazni H, Arya A, Paydar M, Wong WF, Cheah SC, Mustafa MR, Awang K (2013) Antidiabetic and antioxidant properties of alkaloids from Catharanthus roseus (L.) G. Don. Molecules 18(8):9770-9784. https:// doi.org/10.3390/molecules 18089770

26. Agrawal R, Sethiya NK, Mishra SH (2013) Antidiabetic activity of alkaloids of Aerva lanata roots on streptozotocin-nicotinamide induced type-II diabetes in rats. Pharm Biol 51(5):635-642. https://doi.org/10.3109/13880209.2012. 761244

27. Li MY, Xiao Q, Pan JY, Wu J (2009) Natural products from semi-mangrove flora: source, chemistry and bioactivities. Nat Prod Rep 26(2):281-298. https://doi.org/10.1039/B816245J

28. Alikunhi NM, Kandasamy K, Manoharan C, Subramanian M (2012) Insulin-like antigen of mangrove leaves and its anti-diabetic activity in alloxan-induced diabetic rats. Nat Prod Res 26(12):1161-1166. https://doi.org/10.1080/14 786419.2011 .562205

29. Haque M, Ahmed A, Nasrin S, Rahman MM, Raisuzzaman S (2013) Revelation of mechanism of action of Rhizome mucornata Poir. bark extracts for its antidiabetic activity by gut perfusion and six segment method in long evan rats. Int Res J Pharm 4(5):1-4. https://doi.org/10. 7897/2230-8407.04522

\section{Publisher's Note}

Springer Nature remains neutral with regard to jurisdictional claims in published maps and institutional affiliations.

\section{Submit your manuscript to a SpringerOpen ${ }^{\circ}$ journal and benefit from:}

- Convenient online submission

- Rigorous peer review

- Open access: articles freely available online

- High visibility within the field

- Retaining the copyright to your article

Submit your next manuscript at $\boldsymbol{\nabla}$ springeropen.com 